\title{
Assistive technologies for the blind: key competences for health promotion under the Galway Consensus
}

\author{
Tecnologias assistivas para cegos: competências essenciais para promoção da saúde \\ conforme Consenso de Galway
}

Luciana Vieira de Carvalho ${ }^{1}$, Gleicia Martins de Melo ${ }^{1}$, Priscila de Souza Aquino ${ }^{1}$, Régia Christina Moura Barbosa Castro $^{1}$, Maria Vera Lúcia Moreira Leitão Cardoso ${ }^{1}$, Lorita Marlena Freitag Pagliuca ${ }^{1}$

Objective: to identify the key competence domains defined in the Galway Consensus Conference Statement present in assistive technologies to promote the health of blind adults. Methods: integrative review carried out in the Latin American and Caribbean Health Sciences Literature, SCOPUS, Cumulative Index to Nursing and Allied Health Literature, and Medical Publications portal. After application of inclusion criteria, the sample consisted of 10 articles. Eight competencies for health promotion were analyzed: Catalyzing change, Leadership, Assessment of needs, Planning, Implementation, Advocacy, and Partnerships. Results: the competences Catalyzing change and Partnerships prevailed, present in all articles. No study approached the Leadership and Advocacy. Conclusion: the competences Catalyzing change, Assessment of needs, Planning, Implementation, Evaluation and Partnerships were observed in technologies for promoting the health of blind adults.

Descriptors: Technology, Health Promotion, Visually Impaired Persons; Blindness.

Objetivo: identificar os domínios das competências essenciais definidos na Declaração de Consenso de Galway presentes em tecnologias assistivas para promoção da saúde de adultos cegos. Métodos: revisão integrativa realizada nas bases de dados Literatura Latino-Americana em Ciências de Saúde, SCOPUS, Cumulative Index to Nursing and Allied Health Literature, e portal Publicações Médicas. Após aplicação dos critérios de inclusão, a amostra constituiu de 10 artigos. Analisou-se oito competências para promoção da saúde: Catalisar mudança, Liderança, Avaliação das necessidades, Planejamento, Implementação, Advocacia e Parcerias. Resultados: as competências Catalisar mudança e Parcerias prevaleceram, sendo identificadas em todos os artigos. Nenhum estudo trabalhou a competência de Liderança e Advocacia. Conclusão: contemplou-se as competências Catalisar mudança, Avaliação das necessidades, Planejamento, Implementação, Avaliação e Parcerias em tecnologias para promoção da saúde de adultos cegos.

Descritores: Tecnologia; Promoção da Saúde; Pessoas com Deficiência Visual; Cegueira.

$\overline{{ }^{1} \text { Universidade Federal do }}$ Ceará, Fortaleza, Ceará, Brazil. 


\section{Introduction}

There is a high prevalence of blind people in Brazil. Of the 46 million (23.9\%) people with disabilities, $18.8 \%$ are visually impaired and $1.6 \%$ are totally blind $^{(1)}$.

As a result of altered visual function, blind people experience restrictions that compromise interaction with other individuals and with the environment, the execution of daily tasks and the practice self-care. These aspects are responsible for loss of autonomy and dependence on other people. In order to transform this reality, strategies to promote the development of individual abilities of this population, with extension to family and society, need to be implemen$\operatorname{ted}^{(2)}$.

In this perspective, the construction of technologies to enable the blind to access health information stand out, assisting them in carrying out the activities of daily life. There are assistive technologies directed to this population group defined as resources to provide the expansion of functional abilities of disabled people. They promote independence and social inclusion through communication, mobility, environmental control, learning skills, work and integration with family, friends and society ${ }^{(3)}$.

The construction of assistive technologies respects the right of blind people to have access to health, according to the National Policy on Health Promotion. These initiatives represent the understanding that health promotion is characterized by the empowerment of individuals with the purpose of improving their quality of and condition of life, leading to greater participation in this process ${ }^{(4)}$. Concern with the inclusion of all citizens, with or without disabilities, in health actions is evident in the guidelines.

It is pertinent to mention public policies that highlight the importance of health actions aimed at promoting the health of blind people. Their focus is on the implementation of promotion, prevention and rehabilitation activities to improve the individuals' performance in face of daily needs. Among the guide- lines, the organization of services to promote equal access, training of health professionals to provide adequate care to people with disabilities, improvement of communication methods of health information through the construction of educational materials adapted to this population and adoption of educational processes to sensitize the choice of healthy life habits stand out $^{(5)}$.

The Galway Consensus Statement, serves as a basis for implementing health promotion actions through standardization of key competencies, encouraging the adoption of quality practices by health professionals by specifying new attitudes in the work process. The document also highlights the values and principles of health promotion based on determinants of health, equity, social justice and respect for diversity. It also determines key competencies to promote health in the following domains: Catalyzing change, Leadership, Assessment of needs, Planning, Implementation, Evaluation, Advocacy, and Partnerships ${ }^{(6)}$.

Thus, technologies adapted to the blind are included in this context because they represent tools that contribute to health promotion, respect for diversity, in addition to encouraging, through innovative methods, the training of individuals to carry out self-care.

In this context, the present study had the objective of identify the key competencies defined in Galway Consensus Statement present in technologies to promote the health of blind adults.

\section{Methods}

Integrative review carried out in six stages: establishment of the guiding question, formulation of inclusion and exclusion criteria, definition of the information to be extracted from the selected research studies, assessment of studies included in the integrative review, interpretation of results, presentation of the review and synthesis of knowledge ${ }^{(7)}$.

The following question guided the search in databases: what competencies, as defined in the 
Galway Consensus Statement, have been identified in scientific productions on technologies to promote the health of blind adults?

Inclusion criteria were: research available electronically in the databases and in the portal, published in Portuguese, English or Spanish; research answering the question of the study; research carried out with blind adults over the age of 18 years. Editorials or letters to the editor; articles of reflection; systematic reviews, narratives or integrative; studies not published in scientific journals (for example, summaries or dissertations) and articles duplicated in the databases and the portal were excluded.

A bibliographic survey was carried out in $\mathrm{Au}-$ gust and September 2015 by two evaluators separately. The search was made in three databases and in the portal, in the following sequence: Latin American Literature in Health Sciences (LILACS), SCOPUS, Cumulative Index to Nursing and Allied Health Literature (CINAHL), and Medical Publications (PubMed). The search was completed on September 10, 2015.

The controlled Health Science Descriptors (DeCS) "technology", "health promotion" and "people with visual impairment" or "blindness" were used to search in the LILACS database, and the Medical Subject Headings (MeSH) technology, health promotion and visually impaired persons or blindness were used to search in the other database. The filter "full text" was used in the SCOPUS, CINAHL and PubMed databases.

The same sequence was followed in the insertion of descriptors for searching in the chosen databases and in the portal. No time delimitation was established for the search in order to cover the larger number of publications regarding the subject studied. Descriptors were selected after consulting the DeCS and MeSH. In the selection phase, the titles were read first, then the abstract, and then the full text.

The search in the databases and in the portal with the combination of the described descriptors resulted in 3,129 publications, four in LILACS, 11 in SCO-
PUS, 1,212 in CINAHL and 1,902 in PubMed, of which 10 met the inclusion criteria.

The articles were excluded for the following reasons: four were electronically unavailable (two in SCOPUS and two in PubMed); eight were editorials or expert opinions (CINAHL); two were dissertations (LILACS); six were systematic, narrative or integrative reviews (three in CINAHL, three in PubMed); 3,096 did not address the research question (one in LILACS, eight in SCOPUS, 1,196 in CINAHL and 1,891 in PubMed) and three were duplicated (one in SCOPUS, two in PubMed).

For definition of the information to be extracted, a data collection form was prepared with identification of the articles: objective, type of technology, actions of professionals to promote health and competence domains. The results were organized into figures and analyzing according to the eight competence domains for health promotion practice set out in the Galway Consensus Statement.

\section{Results}

The sample consisted of 10 articles, seven available in English and three in Portuguese, published between the years 2004 and 2014. Four of the analyzed publications were clinical trials, two did not specify the research design, the others were: a methodological study, a research, a study on construction and evaluation of assistive technology, and a study on the development of assistive technology.

The evaluation of the efficacy of the technology was the main objective in nine studies. In all articles, the actions of professionals to promote health were related to improving the performance of the blind persons to perform a specific activity. As regards the competence domains, it was observed that Catalysing change and Partnerships were present in all studies. Figure 1 shows the information obtained from each article: objective, type of technology, actions of professionals to promote health and competence domains. 


\begin{tabular}{|c|c|c|c|}
\hline Objective of the study & Type of technology & $\begin{array}{l}\text { Professional actions to } \\
\text { promote health }\end{array}$ & Competence domain \\
\hline $\begin{array}{l}\text { To describe the adaptation } \\
\text { and evaluation of technology } \\
\text { to support the Portuguese } \\
\text { culture }^{(8)}\end{array}$ & $\begin{array}{l}\text { Support technology on supplementary } \\
\text { feeding available through online access. }\end{array}$ & $\begin{array}{l}\text { To increase communication } \\
\text { and improve people's quality } \\
\text { of life. }\end{array}$ & $\begin{array}{l}\text { Catalyzing change } \\
\text { Assessment of needs } \\
\text { Planning } \\
\text { Partnerships }\end{array}$ \\
\hline $\begin{array}{l}\text { To build and evaluate } \\
\text { an educational game on } \\
\text { psychoactive drugs }^{(9)}\end{array}$ & Tactile board game. & $\begin{array}{l}\text { To promote access to } \\
\text { information on drugs in a } \\
\text { creative and playful way. }\end{array}$ & $\begin{array}{l}\text { Catalyzing change } \\
\text { Planning } \\
\text { Implementation } \\
\text { Evaluation } \\
\text { Partnerships }\end{array}$ \\
\hline $\begin{array}{l}\text { To investigate the usability of } \\
\text { Dosvox }^{(10)}\end{array}$ & $\begin{array}{c}\text { Dosvox Assistive Technology for web } \\
\text { access. }\end{array}$ & $\begin{array}{l}\text { To improve the familiarity of } \\
\text { blind people with the use of } \\
\text { computers. }\end{array}$ & $\begin{array}{l}\text { Catalyzing change } \\
\text { Planning } \\
\text { Implementation } \\
\text { Evaluation } \\
\text { Partnerships }\end{array}$ \\
\hline $\begin{array}{l}\text { To evaluate the safety } \\
\text { and usefulness of retinal } \\
\text { prosthesis }^{(11)}\end{array}$ & $\begin{array}{l}\text { Retinal prosthesis with intraocular } \\
\text { (electrodes) and extra-ocular (glasses, } \\
\text { camera, transmitter, video processor } \\
\text { and battery) components. }\end{array}$ & $\begin{array}{l}\text { To improve the performance } \\
\text { in orientation and mobility } \\
\text { tasks. }\end{array}$ & $\begin{array}{l}\text { Catalyzing change } \\
\text { Assessmentof needs } \\
\text { Planning } \\
\text { Implementation } \\
\text { Evaluation } \\
\text { Partnerships }\end{array}$ \\
\hline $\begin{array}{l}\text { To investigate ocular side } \\
\text { effects and possible changes } \\
\text { in quality of life two years } \\
\text { after implantation of retinal } \\
\text { prosthesis }^{(12)}\end{array}$ & $\begin{array}{l}\text { Retinal prosthesis with intraocular } \\
\text { (electrodes) and extra-ocular } \\
\text { (glasses, computer and transmitter) } \\
\text { components. }\end{array}$ & $\begin{array}{l}\text { To investigate the prosthesis } \\
\text { action on the structural and } \\
\text { functional integrity of the eyes } \\
\text { and to improve the quality of } \\
\text { life related to vision. }\end{array}$ & $\begin{array}{l}\text { Catalyzing change } \\
\text { Assessmentof needs } \\
\text { Planning } \\
\text { Implementation } \\
\text { Evaluation } \\
\text { Partnerships }\end{array}$ \\
\hline $\begin{array}{l}\text { To test a hearing device } \\
\text { for interpretation of visual } \\
\text { information }{ }^{(13)}\end{array}$ & $\begin{array}{c}\text { Sensory - auditory substitution } \\
\text { that converts images into sounds, } \\
\text { preserving visual details in high } \\
\text { resolution, consisting of a video camera } \\
\text { connected to a computer and stereo } \\
\text { headphones. }\end{array}$ & $\begin{array}{l}\text { To rehabilitate the visual } \\
\text { function. }\end{array}$ & $\begin{array}{l}\text { Catalyzing change } \\
\text { Assessment of needs } \\
\text { Planning } \\
\text { Implementation } \\
\text { Evaluation } \\
\text { Partnerships }\end{array}$ \\
\hline $\begin{array}{l}\text { To test the effectiveness of } \\
\text { BrainPort technology }{ }^{(14)}\end{array}$ & $\begin{array}{l}\text { BrainPort vision technology, which } \\
\text { consists of digital video camera, zoom } \\
\text { controller, inversion contrast and } \\
\text { electrode array. }\end{array}$ & $\begin{array}{l}\text { Show how technology helps } \\
\text { users in visual activities. }\end{array}$ & $\begin{array}{l}\text { Catalyzing change } \\
\text { Implementation } \\
\text { Partnerships }\end{array}$ \\
\hline $\begin{array}{l}\text { Building an assistive } \\
\text { technology on breastfeeding to } \\
\text { be validated by blind people }{ }^{(15)}\end{array}$ & Singing verses ("cordel"). & $\begin{array}{l}\text { To explain, guide and } \\
\text { encourage the family about } \\
\text { the breastfeeding process. }\end{array}$ & $\begin{array}{l}\text { Catalyzing change } \\
\text { Assessment of needs } \\
\text { Partnerships }\end{array}$ \\
\hline $\begin{array}{l}\text { To help three participants with } \\
\text { multiple acquired disabilities } \\
\text { to get dressed by themselves } \\
\text { through the updated version of } \\
\text { the technology }(16)\end{array}$ & $\begin{array}{l}\text { Assistive technology for the blind: } \\
\text { optical sensor connected to two } \\
\text { cassette players (with music and voice). } \\
\text { Assistive technology for the blind } \\
\text { and deaf: sensor fixed on the dresser, } \\
\text { activated when clothes or shoes are } \\
\text { taken, with vibration in the chair. }\end{array}$ & $\begin{array}{l}\text { Promote self-help, social } \\
\text { image and independence } \\
\text { skills; } \\
\text { Keep motivation. }\end{array}$ & $\begin{array}{l}\text { Catalyzing change } \\
\text { Implementation } \\
\text { Evaluation } \\
\text { Partnerships }\end{array}$ \\
\hline $\begin{array}{l}\text { To analyze a project of an } \\
\text { interactive voice system using } \\
\text { the voice service technology } \\
\text { named Extended Mark up } \\
\text { Language }{ }^{(17)}\end{array}$ & $\begin{array}{l}\text { Assistive technology for web voice } \\
\text { service. }\end{array}$ & $\begin{array}{l}\text { To improve the access to } \\
\text { information services. }\end{array}$ & $\begin{array}{l}\text { Catalyzing change } \\
\text { Implementation } \\
\text { Partnerships }\end{array}$ \\
\hline
\end{tabular}

Figure 1 - Characteristics of the included studies according to the competence domains of the Galway Consensus Statement for health promotion 


\section{Discussion}

This study presents as limitation the fact that the research was carried out in three databases and one portal, restricting the search for articles addressing the theme in question. Therefore, further research in all databases available in the medium term is suggested.

The Galway Consensus Statement presents the key competencies for health promotion, whose characteristics unify and organize caregiving actions. The main objective of this document is to establish and share, on an international basis, common competency-based health promotion practices. The relevance of this comes from the fact that a competent workforce is able to transform public policy guidelines into real and effective initiatives of health promotion to many populations and scenarios, avoiding inequalities in the actions. In this way, the document contributes to the qualification of professionals by encouraging the adoption of new knowledge and ways of working ${ }^{(6)}$.

Assistive technologies consist of new work strategies, since they are innovative resources in the health field for the blind public. The professional is required to know about the peculiarities of the assisted clientele and to elaborate material following certain standards of accessibility. To this end, technologies must be developed with specific properties in order to make them suitable for the use by these people and effective for health promotion. In this context, the competences stipulated in the Galway Consensus Statement should be included in the structural framework of these tools.

In the analyzed articles, it was observed that the competencies Catalyzing change, Assessment of needs, Planning, Implementation, Evaluation and Partnerships were contemplated during the construction of technologies. It should be noted that two competencies, Leadership and Advocacy, were not present in the studies.

Catalyzing change comprises the possibility of modifying behaviors, as well as empowering individu- als and the community in order to improve health ${ }^{(6)}$. The fact that this characteristic was present in all studies proves that professionals are concerned with building technologies to stimulate the participation of the blind in daily activities associated to motivation to choose health-friendly attitudes.

Empowerment is the main goal of health promotion. Empowering individuals means that they are made able to go beyond individual knowledge and begin to participate in more complex social, economic and political situations ${ }^{(18)}$. In this perspective, the use of accessible technological resources represents a relevant strategy for inclusion of the blind in health training processes; they allow access to educational content and daily activities without depending on others.

It was found in the articles analyzed that the technologies contributed to the empowerment of blind persons, contemplating aspects of the competence 'Catalyzing change'.

The studies developed accessible educational materials on breastfeeding ${ }^{(15)}$, complementary feeding to infants ${ }^{(8)}$ and drugs ${ }^{(9)}$. All of these themes are qualified as health education strategies to disseminate knowledge, provoke reflections and discussions, encourage behavior change, clarify doubts, stimulate independence, generate learning, facilitate decision making, exchange experiences among participants, and assist in solving everyday problems.

Other studies have built technologies to assist blind people in performing daily activities, stimulating autonomy in personal care and consequent behavior change $\mathrm{e}^{(14,16-17)}$.

Often, people with disabilities have their abilities underestimated. Families have a protective attitude, causing the development of a dependent individual, with limited performance of basic functional activities and difficulties to solve their problems. Therefore, the offer of accessibility to this public reduces the barriers to interaction with the environment and promotes participation in activities of daily living, essential processes to generate independence and to improve the quality of life ${ }^{(19)}$. 
Another competence highlighted in the articles was the Assessment of needs. This addresses the targeting of actions to specific population groups, respecting their cultural, social, environmental and organizational contexts, and leads to the identification of determinants that favor or compromise health ${ }^{(6)}$.

Aspects affecting the health of blind individuals were observed in some studies. These aspects make them more vulnerable to developing diseases and justify the need for special attention and for developing materials compatible with the reality of current life $^{(8,11-13,15)}$.

Problems that cause health damage, either of individual, social and/or environmental nature, must be evaluated by health professionals to outline specific actions of health promotion ${ }^{(20)}$. The assessment of individual characteristics and needs of participants was seen in two studies on retinal prosthesis implant ${ }^{(11-12)}$. These are essential measures to ascertain the accuracy of the use of the technology and the clinical evolution after the intervention.

Another study described the adaptation of assistive technologies on complementary feeding of infants produced in Brazil to Portuguese culture. In this case, it was necessary to learn the food patterns of the Portuguese population and to make modifications in the content to adapt the material to the cultural reality of the region. With the incorporation of Portuguese typical foods, peculiarities of the local cuisine were respected, and the technological resource was evaluated by the participants as suitable for use and favorable to the health promotion ${ }^{(8)}$.

In turn, the low socioeconomic condition was regarded in an experimental study as a restrictive factor to the acquisition of technologies aimed at improving health. People with visual impairment living in developing countries will be less benefited if the equipment produced is expensive. It is suggested that technological production take into account the life context of the clientele to be assisted ${ }^{(13)}$.

The Planning competence refers to the development of measurable goals and objectives to be achie- ved, as well as the elaboration of strategies based on theories and practices ${ }^{(6,21)}$. Studies evidenced the development of plans with the purpose of guaranteeing the viability and effectiveness of the technological application $^{(8-13)}$. The planning of the action contributes to obtaining positive results in the process of improving the health of individuals ${ }^{(20)}$.

With the Implementation competence, ethical strategies are sought to be carried out in an effective, efficient and culturally sensitive way, to ensure a greater number of possible improvements in health, including human resources and material management ${ }^{(6,21)}$. In this aspect, the technologies worked on blind participants obtained positive results regarding their implementation, according to the perception of users and of health promoter professionals ${ }^{(9,10-14,16-17)}$.

A study that investigated the usability of Dosvox, a computer system developed at the Federal University of Rio de Janeiro to perform the functions of blind people, found that the technology is effective in the opinion of blind people, with the possibility of becoming similar to the standard Windows interaction $^{(10)}$.

The Extended Mark up Language voice service technology developed to help visually impaired, blind or other disabled people to access local, regional or national newspapers through a key phone showed that this technology was successfully implemented ${ }^{(17)}$.

The Evaluation competence is to determine the extent, effectiveness, and impact of health programs and policies. This includes the use of appropriate evaluation methods to support the improvement of programs on sustainability and dissemination ${ }^{(6,21)}$.

Among the articles included, six confirmed the effectiveness and impact of this Evaluation for the blind, carried out through technologies of board game $^{(9)}$, dressing up ${ }^{(16)}$, retinal prosthesis ${ }^{(11-12)}$, visual information devices ${ }^{(13)}$ and web access ${ }^{(10)}$.

As verified in the study describing the construction and evaluation of assistive technologies of tactile board game in the Nursing Department of the Federal University of Ceará, in 2010, ludic methods 
in the form of educational games represent a positive tool for the teaching and learning process, as arouses interest in a pleasurable way, when addressing the theme of drugs ${ }^{(9)}$.

A clinical trial aimed at investigating the ocular side effects and possible changes in the quality of life in the implantation of the Epiret3 retinal prosthesis in six blind volunteers affected by retinitis pigmentosa showed that the surgery for implantation of the device can be considered safe, although often involves acute adverse reactions and may need improvement in the fixation of the device ${ }^{(12)}$.

The Partnerships competence seeks collaborative work across disciplines, sectors and partners to increase the impact and sustainability of health promotion programs and policies ${ }^{(6,21)}$.

The use of partnership was evident in all studies. It is thus evident that developing technologies for the blind cannot happen without the participation of health care professionals and of other areas. This was confirmed in the study analyzed when the help of the Coordinator and of the technical assistant of the study and of other professionals was necessary for the development of a technology to assist visually impaired users to acquire accurate information about the shapes of the objects presented at various distances via the BrainPort vision device ${ }^{(14)}$.

With respect to the two competencies that were not present in this review, Leadership allows the strategic direction and opportunities to participate in the development of public policies, mobilizing and managing resources to promote health and build skills. The Consensus Statement emphasized that public policies are relevant to health promotion, and that professionals need to be involved in the elaboration and implementation of these policies in order to transform plans into effective practices ${ }^{(6)}$.

Public policies propose the integration of the population in diverse social sectors, such as health, education, work, transportation and leisure. When it comes to blind people, the development of public poli- cies is a demonstration of respect for the social rights of these citizens, allowing greater autonomy and participation in actions that promote health promotion.

Advocacy, in turn, is a competence that defends individuals and communities to improve health, well-being and enhances the ability to perform actions that can both improve health and strengthen the community ${ }^{(6,21)}$.

It is important to emphasize the importance of this competence to empower people to awaken a critical view towards attitudes of a decent quality of life ${ }^{(20)}$. This represents an exercise of effective citizenship, in line with social development of the nation, important for health promotion ${ }^{(22)}$.

\section{Conclusion}

It was identified that the competence domains Catalyzing change, Assessment of needs, Planning, Implementation, Evaluation and Partnerships have been included in technologies to promote the health of blind adults.

\section{Collaborations}

Carvalho LV and Melo GM contributed to the collection, organization, interpretation of data, work design, writing and final approval of the version to be published. Aquino PS and Castro RCMB contributed to the interpretation of the data, writing and critical review relevant content. Cardoso MVLML and Pagliuca LMF contributed to the writing of the article and final approval of the version to be published.

\section{References}

1. Instituto Brasileiro de Geografia e Estatística. Cartilha do Censo 2010: pessoas com deficiência. Brasília: IBGE; 2012.

2. Souza ELV, Moura GN, Nascimento JC, Lima MA, Pagliuca LMF, Caetano JA. Nursing diagnoses based on the self-care theory in people with visual deficiency Rev Rene. 2012; 13(3):542-51. 
3. Sartoretto ML, Bersch R. O que é Tecnologia Assistiva [Internet]. 2016 [citado 2016 nov 1]. Disponível em: http://www.assistiva.com.br/

4. Ministério da Saúde (BR). Política Nacional de Promoção da Saúde: PNPS: revisão da Portaria MS/GM nº 687, de 30 de março de 2006. Brasília: Ministério da Saúde; 2015.

5. World Health Organization. Relatório mundial sobre a deficiência. Tradução Lexicus Serviços Linguísticos. São Paulo: SEDPcD; 2012.

6. Allegrante JP, Barry MM, Airhihenbuwa CO, Auld ME, Collins JL, Lamarre MC, et al. Domains of core competency, standards and quality assurance for building global capacity in health promotion: the Galway Consensus Conference Statement. Health Educ Behav. 2009; 36(3):476-82.

7. Mendes KD, Silveira RC, Galvão CM. Integrative literature review: a research method to incorporate evidence in health care and nursing. Texto Contexto Enferm. 2008; 17(4):758-64.

8. Cezario KG, Abreu MSN, Pagliuca LMF. Alimentação complementar do lactente: adaptação e avaliação de tecnologia de apoio para pais cegos portugueses. Rev Enf Ref. 2014; 4(3):37-44.

9. Mariano MR, Rebouças CBA, Pagliuca LMF. Educative game on drugs for blind individuals: development and assesment. Rev Esc Enferm USP. 2013; 47(4):930-6.

10. Souza ER, Freitas SF. Dosvox usability: recommendations for improving interaction of blind people with the web using the system. Work. 2012; 41(1):3443-48.

11. Humayun MS, Dorn JD, Cruz L, Dagnelie G, Sahel JA, Stanga PE, et al. Interim results from the international trial of second sight's visual prosthesis. Ophthalmology. 2012; 119(4):779-88.

12. Menzel-Severing J, Laube T, Brockmann C, Bornfeld $\mathrm{N}$, Mokwa W, Mazinani B, et al. Implantation and explantation of an active epiretinal visual prosthesis: 2-year follow-up data from the Epiret3 prospective clinical trial. Eye. 2012; 26(4):501-9.

13. Striem-Amit E, Guendelman M, Amedi A. Visual acuity of the congenitally blind using visual-toauditory sensory substitution. Plos One [Internet]. 2012 ]cited 2016 Nov 13]; 7(3):33136. Available from:https://www.ncbi.nlm.nih.gov/pmc/ articles/PMC3306374/pdf/pone.0033136.pdf
14. Williams MD, Ray CT, Griffith J, De l'Aune W. The use of a tactile-vision sensory substitution system as an augmentative tool for individuals with visual impairments. J Visual Impair Blin. 2011; 105(1):45-50.

15. Oliveira PMP, Rebouças CBA, Pagliuca LMF. Construção de uma tecnologia assistiva para validação entre cegos: enfoque na amamentação. Rev Bras Enferm. 2009; 62(6):837-43.

16. Lancioni GE, O’Reilly MF, Singh NN, Sigafoos J, Oliva D, Campodonico F, et al. Helping three persons with multiple disabilities acquire independent dressing through assistive technology. J Visual Impair Blin. 2007; 101(12):768-73.

17. Modukuri R, Morris RJ. Voice based web services: an assistive technology for visually impaired persons. Technol Disabil. 2004; 16(4):195-200.

18. Oliveira KB, Lopes GSC, Watanabe M, Yamaguchi CK, Duarte R. Estudo do empoderamento na perspectiva de mulheres líderes. Pretexto. 2015; 16(4):82-99.

19. Filho TG. Tecnologia Assistiva: favorecendo o desenvolvimento e a aprendizagem em contextos educacionais inclusivos. In: Giroto CRM, Poker RB, Omote $\mathrm{S}$. As tecnologias nas práticas pedagógicas inclusivas. São Paulo: Cultura Acadêmica; 2012. p.1-13.

20. Mariano MR, Pinheiro AKB, Aquino PS, Ximenes LB, Pagliuca LMF. Jogo educativo na promoção da saúde de adolescentes: revisão integrativa. Rev Eletr Enferm [Internet]. 2013 [citado 2016 set. 8]: 15(1):265-73. Disponível em: https://www.fen. ufg.br/fen_revista/v15/n1/pdf/v15n1a30.pdf

21. Battel-Kirk B, Barry MM, Taub A, Lysoby L. A review of the international literature on health promotion competencies: identifying frameworks and core competencies. Global Health Prom. 2009; 16(2):12-20.

22. Germani ACCG, Aith F. Advocacia em promoção da saúde: conceitos, fundamentos e estratégias para a defesa da equidade em saúde. R Dir Sanit. 2013; 14(1):34-59. 